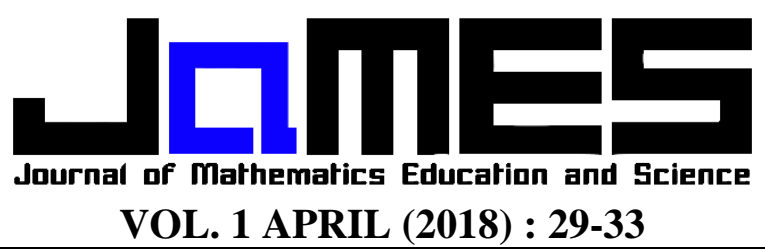

p-ISSN: 2621-1203

e-ISSN: 2621-1211

\title{
ANALISIS MODEL MATEMATIKA PENYEBARAN PENYAKIT H1N1 DENGAN TINGKAT KEJADIAN TERSATURASI
}

\author{
M. Ivan Ariful Fathoni ${ }^{1}$ \\ Universitas Nahdlatul Ulama Sunan Giri, fathoni@ unugiri.ac.id ${ }^{1}$ \\ Received : 5 Maret 2018, Accepted : 1 April 2018, @ Mathematics Education Unugiri 2018
}

\begin{abstract}
Swine flu is an acute respiratory infection that attacks the body's organs especially the lungs. The disease is caused by Influenza Virus Type A, type H1N1. In this article constructed mathematical model of the spread of H1N1 disease. Mathematical model that created the model Susceptible, Exposed, Infective, and Treatment. The existence of behavior change and influence of infected individual density become the reason of model formation with saturation occurrence rate. From the dynamic analysis, the model has two equilibrium points, that is, a stable equilibrium free equilibrium point when the basic reproduction number is less or equal to one, and an endemic equilibrium point that exists and is stable when the basic reproduction number is greater than one. Finally, the results of the analysis prove the control of the spread of disease into a disease-free state.
\end{abstract}

Keywords: dynamic analysis, swine flu, saturated event level, equilibrium point, stability.

\begin{abstract}
Abstrak
Flu babi adalah infeksi saluran pernapasan akut yang menyerang organ tubuh terutama paru-paru. Penyakit ini disebabkan oleh Virus Influenza tipe A, jenis H1N1. Pada artikel ini dikonstruksi model matematika penyebaran penyakit H1N1. Model matematika yang dibuat yaitu model Susceptible, Exposed, Infective, dan Treatment. Adanya perubahan perilaku dan pengaruh kepadatan individu terinfeksi menjadi alasan pembentukan model dengan tingkat kejadian tersaturasi. Dari hasil analisis dinamik, model memiliki dua titik kesetimbangan, yaitu titik kesetimbangan bebas penyakit yang bersifat stabil saat bilangan reproduksi dasar bernilai lebih kecil atau sama dengan satu, dan titik kesetimbangan endemi yang eksis dan bersifat stabil saat bilangan reproduksi dasar bernilai lebih besar dari satu. Pada akhirnya, hasil analisis membuktikan adanya kontrol penyebaran penyakit menjadi keadaan bebas penyakit.
\end{abstract}

Kata kunci: analisis dinamik, flu babi, tingkat kejadian tersaturasi, titik kesetimbangan, kestabilan.

\section{Pendahuluan}

Flu babi (H1N1) adalah infeksi saluran pernapasan akut yang menyerang organ tubuh terutama paru-paru. Penyakit ini disebabkan oleh Virus Influenza tipe A, jenis H1N1. Gejala umum penyakit ini hampir sama dengan influenza biasa dan atau flu burung yaitu ditandai dengan demam (panas tubuh $>39^{\circ} \mathrm{C}$ ) batuk, pilek, lesu, letih, nyeri tenggorokan, nafas cepat (nafas anak umur $<2$ bulan yaitu 60 kali per menit atau lebih, anak umur 2 bln -1 tahun 50 kali per menit atau lebih, anak umur 1 - 5 tahun 40 kali per menit atau lebih), sesak nafas (whezzing atau stridor), kadang-kadang terjadi iritasi pada mata dengan masa inkubasi (virus masuk ke dalam tubuh sampai menimbulkan sakit) antara 3 - 5 hari.

Menurut Kristina [1], agent utama virus ini adalah binatang khususnya babi, tetapi binatang lain seperti kera, kelelawar serta binatang berdarah panas lainnya perlu kita waspadai. Belum ada bukti penyakit flu babi menular dari manusia ke manusia layaknya flu biasa (comond cold) tetapi sifat ganas virus ini memungkinkan untuk menular dari manusia ke manusia. Penularan antar manusia dapat 
disebabkan oleh interaksi antar individu, maupun antar kelompok individu.

Penyakit flu babi tidak bisa hanya dikendalikan oleh pemerintah, tetapi memerlukan dukungan dan keterlibatan pihak swasta, masyarakat, dan peneliti secara aktif. Perkembangan ilmu pengetahuan di dalam matematika turut memberikan peranan yang penting dalam mencegah meluasnya penyebaran penyakit. Peranan tersebut berupa pembentukan model matematika yang dapat menggambarkan penyebaran suatu penyakit di masa yang akan datang dengan melihat kondisi masa sekarang atau masa lalu. Model tersebut disebut dengan model epidemi.

Secara umum, model epidemi mempertimbangkan tingkat kejadian infeksi penyakit (incidence rate). Tingkat kejadian infeksi menyatakan banyaknya kasus infeksi baru akibat interaksi antara individu rentan dengan individu terinfeksi. Capasso dan Serio [2] memperkenalkan tingkat kejadian infeksi nonlinear yang disebut tingkat kejadian infeksi tersaturasi. Tingkat kejadian semacam ini lebih efektif karena mempertimbangkan perubahan perilaku dan pengaruh kepadatan individu terinfeksi. Pada penelitian pemodelan penyakit H1N1 yang telah dilakukan selama ini masih menggunakan tingkat kejadian linier. Sehingga perlu untuk mengkaji model epidemi penyakit H1N1 dengan menggunakan tingkat kejadian tersaturasi.

Penyebaran suatu penyakit dapat dikendalikan dengan pemberian terapi. Oleh karena itu, terapi perlu dilakukan sebagai salah satu upaya untuk mencegah penyebaran penyakit. Kontrol terapi vaksinasi digunakan oleh El hia, dkk. [3] untuk mengendalikan penyebaran penyakit Influenza A (H1N1). El hia, dkk. memodelkan penyebaran penyakit H1N1 dengan model SIR, dan memberikan kontrol (vaksinasi) yang optimal untuk meminimalkan jumlah individu terinfeksi dan biaya vaksinasi. Berbeda dengan penelitian yang telah dilakukan oleh El hia, pada penelitian ini, model yang digunakan adalah model SEIT.
Model epidemi H1N1 dengan adanya terapi pada penelitian ini terdiri dari empat kelompok (kompartemen), yaitu kelompok populasi rentan (Susceptible), kelompok populasi dengan masa inkubasi (Exposed), kelompok populasi terinfeksi penyakit (Infective), dan kelompok populasi dari individu-individu yang telah mendapat tritmen (Treatment). Analisis perilaku dinamis dari ke empat populasi tersebut dibahas dalam penelitian ini dengan tujuan untuk dapat mengetahui parameter-parameter yang dapat dikendalikan dalam upaya meminimalisir penyebaran penyakit.

\section{Metode Penelitian}

Pada artikel ini dikonstruksi model epidemi Susceptible, Exposed, Infective, dan Treatment. Analisis dinamik terhadap model dilakukan untuk memperoleh titik-titik kesetimbangan, bilangan reproduksi dasar, dan syarat eksistensi serta kestabilan titik-titik kesetimbangan model. Pada bagian akhir, analisis yang telah diperoleh disimulasikan dengan menggunakan software Matlab. Program simulasi yang telah dibuat dijalankan dengan variasi nilai awal, serta variasi nilai parameter yang memenuhi tiga kondisi, yaitu saat $\mathcal{R}_{0}>1, \mathcal{R}_{0}=1$, dan $\mathcal{R}_{0}<1$. Output program simulasi dianalisis untuk memastikan hasil yang sesuai dengan hasil analisis dinamik.

\section{Hasil dan Pembahasan}

\subsection{Konstruksi Model}

Model dikonstruksi dari model epidemi Susceptible, Exposed, Infective, dan Treatment dengan tritmen pada populasi exposed. Laju perubahan populasi susceptible, exposed, infective, dan treatment adalah sebagai berikut.

a. Laju perubahan populasi susceptible.

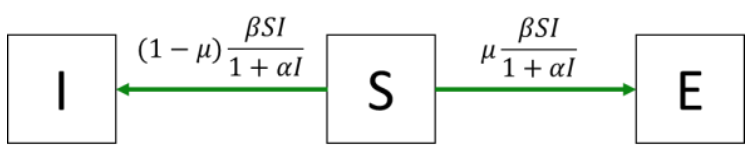

Gambar 1. Diagram kompartemen interaksi $S(t)$ dan $I(t)$ 
Berdasarkan diagram kompartemen pada Gambar 1. dan 2., model laju perubahan populasi susceptible per satuan waktu, yaitu

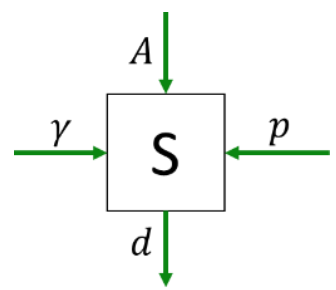

Gambar 2. Diagram kompartemen populasi susceptible

$$
\begin{gathered}
\dot{S}(t)=A-d S(t)-\frac{\beta S(t) I(t)}{1+\alpha I(t)}+\gamma I(t) \\
+p T(t) .
\end{gathered}
$$

b. Laju perubahan populasi exposed.

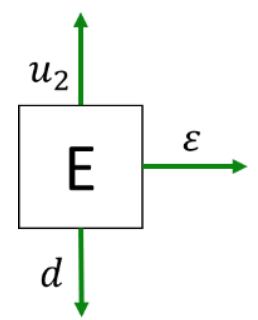

Gambar 3. Diagram kompartemen populasi exposed

Adanya terapi pada individu exposed mengakibatkan adanya individu exposed yang sembuh dengan tingkat pengobatan $\boldsymbol{u}$, sehingga $\boldsymbol{-} \boldsymbol{u} \boldsymbol{E}$ menyatakan berkurangnya populasi akibat individu exposed sembuh dengan pengobatan tiap waktu, seperti pada Gambar 3. Dengan demikian persamaan menjadi

$\dot{E}(t)=\mu \frac{\beta S(t) I(t)}{1+\alpha I(t)}-(d+\varepsilon+u) E(t)$.

c. Laju perubahan populasi infective.

Berdasarkan diagram kompartemen pada Gambar 1. dan 4., model laju perubahan populasi infective per satuan waktu, yaitu

$$
\begin{aligned}
\dot{I}(t)=(1-\mu) & \frac{\beta S(t) I(t)}{1+\alpha I(t)}+\varepsilon E(t) \\
& -(d+\gamma+\delta) I(t) .(3)
\end{aligned}
$$

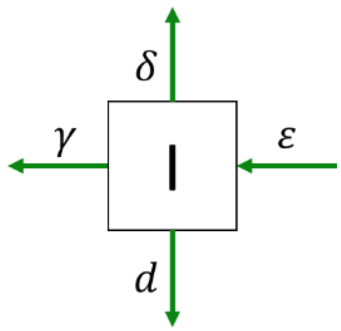

Gambar 4. Diagram kompartemen populasi infective

d. Laju perubahan populasi treatment.

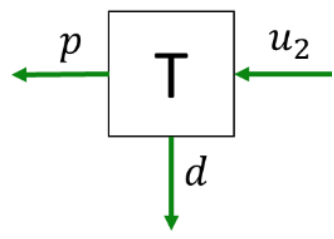

Gambar 5. Diagram kompartemen populasi treatment

Adanya individu exposed yang diberi pengobatan mengakibatkan bertambahnya populasi treatment dengan tingkat $u$, sehingga $u E$ menyatakan bertambahnya populasi akibat individu exposed sembuh dengan pengobatan tiap waktu, seperti pada Gambar 5. Dengan demikian persamaan menjadi

$$
\dot{T}(t)=u E(t)-(p+d) T(t) .
$$

Berikut ini adalah tabel laju perubahan keempat populasi tiap waktu berdasarkan persamaan (1), (2), (3), dan (4).

Dari Tabel 1. diperoleh laju perubahan populasi susceptible, exposed, infective dan treatment. Laju perubahan populasi-populasi tersebut memenuhi sistem persamaan diferensial nonlinear berikut.

$$
\begin{aligned}
& \dot{S}(t)= A-d S(t)-\frac{\beta S(t) I(t)}{1+\alpha I(t)}+\gamma I(t) \\
&+p T(t) \\
& \dot{E}(t)= \mu \frac{\beta S(t) I(t)}{1+\alpha I(t)}-\left(d+\varepsilon+u_{2}\right) E(t) \\
& \dot{I}(t)=(1-\mu) \frac{\beta S(t) I(t)}{1+\alpha I(t)}+\varepsilon E(t) \quad-(d+\gamma+\delta) I(t) \\
& \dot{T}(t)=u E(t)-(p+d) T(t),
\end{aligned}
$$


dengan $u$ adalah tingkat pengobatan populasi exposed. Diagram kompartemen dari sistem secara skematis disajikan dalam Gambar 6. berikut.

Tabel 1. Laju perubahan populasi

\begin{tabular}{|c|c|c|c|c|}
\hline \multirow{2}{*}{ Faktor } & \multicolumn{4}{|c|}{ Laju perubahan populasi tiap waktu $\left(\frac{d}{d t}\right)$} \\
\cline { 2 - 5 } & Susceptible & Exposed & Infective & $\begin{array}{c}\text { Treat- } \\
\text { ment }\end{array}$ \\
\hline Kelahiran & $A$ & & & \\
\hline Kematian & $-d S(t)$ & $-d E(t)$ & $-(d+\delta) I(t)$ & $-d T(t)$ \\
\hline $\begin{array}{l}\text { Interaksi } S \\
\text { dan } I\end{array}$ & $-\frac{\beta S(t) I(t)}{1+\alpha I(t)}$ & $\mu \frac{\beta S(t) I(t)}{1+\alpha I(t)}$ & $(1-\mu) \frac{\beta S(t) I(t)}{1+\alpha I(t)}$ & \\
\hline $\begin{array}{l}\text { Perubahan } \\
\text { sifat } E \\
\text { menjadi } I\end{array}$ & $\gamma I(t)$ & $-\varepsilon E(t)$ & $\varepsilon E(t)$ & \\
\hline $\begin{array}{l}\text { Perubahan } \\
\text { sifat } I \\
\text { menjadi } S\end{array}$ & $p T(t)$ & $-u E(t)$ & $-\gamma I(t)$ & \\
\hline $\begin{array}{l}\text { Perubahan } \\
\text { sifat } T \\
\text { menjadi } S\end{array}$ & & & & $-p T(t)$ \\
\hline Tritmen & & & & \\
\hline
\end{tabular}

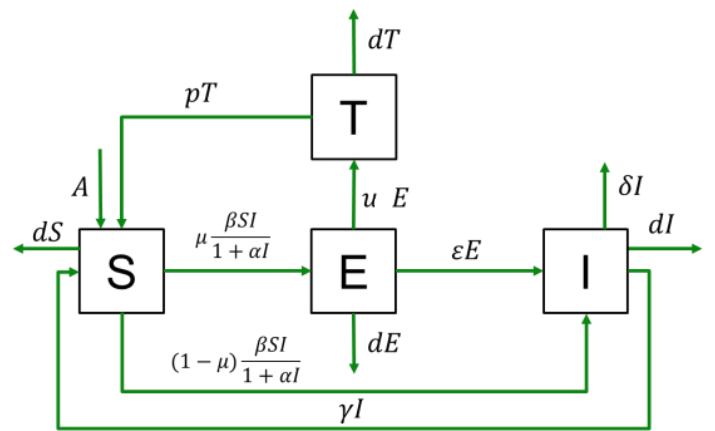

Gambar 6. Diagram Kompartemen

Model yang dinyatakan dalam sistem diubah menjadi bentuk EITN, dengan mensubstitusikan $S=N-E-I-T$ ke sistem, diperoleh

$$
\begin{aligned}
& \dot{E}=\mu \frac{\beta I}{1+\alpha I}(N-E-I-T)-(d+\varepsilon \\
& \left.+u_{2}\right) E \\
& \dot{I}=(1-\mu) \frac{\beta I}{1+\alpha I}(N-E-I-T)+\varepsilon E \\
& \dot{T}=u E-(p+d) T \\
& -(d+\gamma+\delta) I \\
& \dot{N}=A-d N-\delta I \text {, }
\end{aligned}
$$

dengan

$$
\begin{gathered}
E \geq 0, I \geq 0, T \geq 0, N \geq 0, \\
E+I+T \leq N \leq \frac{A}{d}
\end{gathered}
$$

\subsection{Titik Kesetimbangan}

Jika $I=0 \quad$ diperoleh titik kesetimbangan bebas penyakit

Jika $I \neq 0$ maka

$$
P^{0}\left(E^{0}, I^{0}, T^{0}, N^{0}\right)=\left(0,0,0, \frac{A}{d}\right) .
$$

$$
\begin{aligned}
u E-(p+d) T & =0 \\
(p+d) T & =u E \\
T & =\frac{u E}{p+d}
\end{aligned}
$$

Sehingga diperoleh titik kesetimbangan endemi yaitu $P^{*}\left(E^{*}, I^{*}, T^{*}, N^{*}\right)$ dengan

$$
\begin{aligned}
E^{*} & =\frac{\mu n}{(m+u)(1-\mu)+\mu \varepsilon} I^{*} \\
I^{*} & =\frac{\frac{(m+u) n}{(m+u)(1-\mu)+\mu \varepsilon}\left[\frac{\beta A((m+u)(1-\mu)+\mu \varepsilon)}{(m+u) n d}-1\right]}{\beta\left(\frac{\delta}{d}+\frac{\mu n}{(m+u)(1-\mu)+\mu \varepsilon}+1\right)+\frac{\alpha(m+u) n}{(m+u)(1-\mu)+\mu \varepsilon}} \\
T^{*} & =\frac{u E^{*}}{p+d} \\
N^{*} & =\frac{A}{d}-\frac{\delta I^{*}}{d}
\end{aligned}
$$

Dari titik kesetimbangan endemi diperoleh bilangan reproduksi dasar

$$
\mathcal{R}_{0}=\frac{\beta A((m+u)(1-\mu)+\mu \varepsilon)}{(m+u) n d}
$$

sehingga jika $\mathcal{R}_{0}<1$ maka hanya terdapat satu titik kesetimbangan yang eksis yaitu titik kesetimbangan bebas penyakit. Sedangkan jika $\mathcal{R}_{0}>1$ maka terdapat dua titik kesetimbangan yang eksis, yaitu titik kesetimbangan bebas penyakit dan titik kesetimbangan endemi.

\subsection{Kestabilan}

Berdasarkan analisis kestabilan titik kesetimbangan, jika $\mathcal{R}_{0}=1$ diperoleh

$$
\begin{aligned}
1 & =\frac{\beta A((m+u)(1-\mu)+\mu \varepsilon)}{(m+u) n d} \\
(m+u) n d & =\beta A((m+u)(1-\mu)+\mu \varepsilon)
\end{aligned}
$$


und $-\beta A u(1-\mu)=\beta A(m(1-\mu)+\mu \varepsilon)-m n d$

$u(n d-\beta A(1-\mu))=\beta A(m(1-\mu)+\mu \varepsilon)-m n d$

$$
u=\frac{\beta A(m(1-\mu)+\mu \varepsilon)-m n d}{n d-\beta A(1-\mu)}
$$

yang merupakan ambang batas bifurkasi. Jika $\mathcal{R}_{0}>1$ atau parameter pengobatan $u<$ $\frac{\beta A(m(1-\mu)+\mu \varepsilon)-m n d}{n d-\beta A(1-\mu)}$, maka titik kesetimbangan endemi stabil sedangkan titik kesetimbangan bebas penyakit tidak stabil. Sebaliknya jika $\mathcal{R}_{0}<1$ atau $u>\frac{\beta A(m(1-\mu)+\mu \varepsilon)-m n d}{n d-\beta A(1-\mu)}$, maka hanya terdapat satu titik kesetimbangan, yaitu titik kesetimbangan bebas penyakit yang bersifat stabil. Dari penjelasan tersebut diketahui bahwa semakin bertambahnya $u$ maka semakin mendekati kondisi bebas penyakit. Dengan kata lain, pemberian tritmen pada populasi exposed juga dapat meminimalisir penyebaran penyakit di suatu wilayah.

\section{Kesimpulan}

Penyebaran penyakit $\mathrm{H} 1 \mathrm{~N} 1$ di suatu interaksi populasi dapat dimodelkan secara matematis dalam bentuk sistem autonomous nonlinear dengan empat variabel tak bebas. Berdasarkan analisis kestabilan titik kesetimbangan, penyebaran penyakit dapat dikendalikan dengan mengontrol parameterparameter sehingga $\mathcal{R}_{0}<1$. Jika dalam keadaan $\mathcal{R}_{0}<1$, maka dapat dikontrol menjadi keadaan bebas penyakit, artinya penyakit H1N1 akan hilang seiring berjalannya waktu.

\section{Referensi}

[1] Ni Nyoman Kristina, Widyaiswara Muda Dinas Kesehatan Provinsi Bali, diambil dari http://www.diskes.baliprov.go.id/id/FLU-

BABI--H1N1-, pada tanggal 12 Februari 2018.

[2] Capasso, V. \& Serio, G., A Generalization of the Kermack-McKendrick Deterministic Epidemic Model. Mathematical Biosciences, Volume 42, (1978). pp. 43-61.

[3] El hia, M., Balatif, O., Bouyaghroumni, J., Labriji, E., \& Rachik, M., Optimal Control Applied to the Spread of Influenza A (H1N1). Applied Mathematical Sciences, 6, (2012). 4057-4065. 
